\title{
PENGARUH KUALITAS PELAYANAN, KUALITAS PRODUK, STORE ATMOSPHERE, DAN E-WOM TERHADAP PROSES KEPUTUSAN PEMBELIAN (SURVEI TERHADAP KONSUMEN ZENBU-HOUSE OF MOZARU PARIS VAN JAVA, BANDUNG)
}

\author{
Alvendo Teguh Santosa \\ Program Studi Magister Manajemen, Universitas Katolik Parahyangan, Bandung \\ Email: alvonsius.vendo88@yahoo.com
}

Submitted: Apr 9, 2018; Reviewed: Apr 10, 2018; Accepted: Mei 30, 2018

\begin{abstract}
Bandung is a city in Indonesia with big tourism potential. Culinary tourism is one of the most iconic tourism themes in Bandung. One of the most demanded culinary is Japanese Fusion style food that Zenbu-House of Mozaru in Paris Van JavaMall (Zenbu PVJ). In order to increase consumer's interest, management needs strategies are based from service quality, product quality, store atmosphere and e-WOM. This study uses non-probability sampling technique with purposive sampling method. Based on index assessment, respondents rate service quality, product quality, and store atmosphere good rating whereas e-WOM is rated with moderate assessment. Overall the purchasing decision process is rated with good assessment. This study uses multiple regression analysis, $t$-test, F-test, and the coefficient of determination analysis as the analysis tools. The result shows that service quality, product quality, store atmosphere, and e-WOM are simultaneously influenced the purchasing decision process of Zenbu PVJ. While partially, service quality, and eWOM influence the purchasing decision process whereas product quality and store atmosphere do not influence the purchasing decision process.
\end{abstract}

Keywords: E-WOM; Product Quality; Purchasing Decision Process; Service Quality; Store Atmosphere

\section{PENDAHULUAN}

Bandung merupakan salah satu kota di Indonesia dengan potensi pariwisata yang cukup tinggi, khususnya di Jawa Barat. Dengan potensi yang begitu besar dan didukung dengan banyaknya pembangunan yang dilakukan oleh pemerintah Kota Bandung, seharusnya dapat semakin memperbesar daya tarik pengunjung dari luar daerah dan diharapkan akan semakin memperbesar peluang bisnis yang ada dan juga semakin memperbesar potensi pendapatan bisnis yang sudah ada. Kota Bandung memiliki banyak objek wisata yang dapat menarik wisatawan dan salah satunya adalah wisata kuliner yang juga sudah menjadi salah satu ciri khas Kota Bandung.

Setiap tahun jumlah restoran dan café di Kota Bandung terus meningkat. Berdasarkan Badan Pusat Statistik (BPS) Kota Bandung
(2017) di tahun 2015 sendiri terjadi peningkatan jumlah restoran dan café yang sangat signifikan yaitu sebanyak 106 rumah makan dan pada tahun 2016 meningkat 36 rumah makan. Tetapi dengan berkurangnya jumlah pengunjung yang datang ke Kota Bandung di tahun 2015 dan 2016 malah membuat persaingan di industri ini semakin ketat. Para pelaku bisnis di industri restoran dan rumah makan harus berusaha lebih keras agar dapat menarik pengunjung untuk bersantap di restoran mereka.

Kota Bandung menawarkan beragam jenis masakan tersedia tetapi salah satu jenis masakan yang sedang naik daun dan sangat diminati adalah masakan Jepang bergaya fusion dan restoran yang menyajikan makanan tersebut dan salah satu yang cukup terkenal di Bandung adalah Zenbu - House of Mozaru (selanjutnya disebut Zenbu PVJ). 
Semakin ketatnya persaingan, terutama di dalam Mal Paris Van Java di mana jumlah restoran yang semakin bertambah membuat Zenbu PVJ perlu melakukan perubahan. Dari hasil wawancara dengan manajer operasional di Zenbu PVJ, diketahui bahwa jumlah pengunjung Zenbu mengalami fluktuasi tiap bulannya dan kecenderungan selama tiga bulan terakhir terlihat jumlah pengunjungnya terus mengalami penurunan. Artinya semakin sedikit calon pengunjung yang memutuskan melakukan pembelian makanan di Zenbu PVJ.

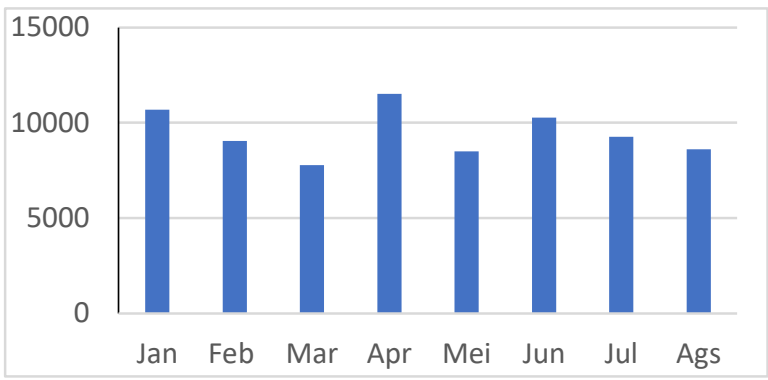

\section{Gambar 1 Jumlah Pengunjung Zenbu PVJ Bandung Bulan Januari sampai dengan Agustus 2017}

Sumber: Data operasional Zenbu PVJ Bandung

Demi mempertahankan eksistensinya dan juga semakin memajukan restorannya Zenbu PVJ perlu melakukan perubahan dan salah satunya adalah dengan memperbaiki sistem pemasarannya. Kotler \& Keller (2013) mengatakan agar dapat tetap bertahan di tengah persaingan dan ketidakpastian, setiap perusahaan dituntut untuk berkembang dan meraih competitive advantage dan salah satunya dengan menerapkan konsep pemasaran modern yang berorientasi pasar atau pelanggan karena mereka merupakan ujung tombak keberhasilan pemasaran.

Restoran perlu meninjau ulang berbagai aspek yang dapat membuat konsumen melakukan pembelian dan bersantap di restoran mereka terutama strategi yang sangat mempengaruhi dalam industri pelayanan dan bagaimana cara perusahaan menyebarluaskan informasi mengenai strategi mereka kepada calon konsumen.

Penelitian terdahulu dari Ryu \& Han (2010) mengatakan kualitas makanan, keadaan lingkungan fisik atau atmosfer dan pelayanan merupakan faktor kunci yang dapat menarik pelanggan untuk bersantap dalam restoran mereka. Campbell \& Smith; dalam Longart (2008) mengemukakan bahwa makanan, atmosfer dan pelayanan adalah elemen kunci 144 yang memperluas daya tarik dari pengalaman bersantap dalam suatu restoran.

Jeong \& Jang (2011) mengatakan bahwa $e-W O M$ sangat penting bagi keputusan pembelian konsumen, terlebih di dalam industri pelayanan. Lewis \& Chambers (2000) menemukan bahwa saat membuat keputusan untuk bersantap dalam suatu restoran melibatkan risiko yang cukup besar dan akhirnya akan membawa konsumen menjadi tergantung pada pengaruh dari $e$-WOM. Mereka juga mengemukakan bahwa dampak positif dari $e$ WOM bagi restoran cukup besar karena dapat membantu restoran membagun kesan positif dan terlebih meningkatkan minat konsumen untuk membeli atau bersantap dalam restoran tersebut.

Penulis melihat fenomena bagaimana suatu restoran dapat bertahan dalam suatu pusat perbelanjaan untuk jangka waktu yang relatif lama (antara 11 tahun) dimana restoran lainnya tidak dapat bertahan dalam menghadapi persaingan dalam industri kuliner yang semakin keras terutama di dalam pusat perbelanjaan di mana banyak alternatif restoran yang ada di dalamya. Berdasarkan penelitian terdahulu dan latar belakang tersebut, maka kualitas pelayanan, kualitas produk, store atmosphere dapat menjadi dasar dari perbaikan strategi dalam industri kuliner. Melalui $e-W O M$, restoran dapat membagikan informasi kepada calon konsumen. Penulis tertarik untuk mengadakan penelitian guna mengetahui apakah terdapat pengaruh kualitas pelayanan, kualitas produk, store atmosphere dan e-WOM terhadap proses keputusan pembelian konsumen. Hasil penelitian juga diharapkan dapat memberikan informasi kepada manajemen Zenbu PVJ yang dapat dijadikan acuan untuk penyusunan strategi pemasaran di masa yang akan datang agar dapat membantu Zenbu PVJ untuk terus bertahan dan berkembang. Hasil penelitian ini juga diharapkan menjadi informasi dan ilmu bagi para pelaku bisnis kuliner lainnya di masa mendatang.

\section{IDENTIFIKASI MASALAH}

Rumusan masalah yang dapat diajukan dalam penelitian ini adalah apakah terdapat pengaruh kualitas pelayanan, kualitas produk, store atmosphere, dan e-WOM terhadap proses keputusan pembelian konsumen Zenbu PVJ baik secara bersama-sama dan parsial.

\section{TUJUAN PENELITIAN}

Tujuan dari penelitian ini adalah untuk menganalisis pengaruh kualitas pelayanan, kualitas produk, store atmosphere, dan e-WOM 
terhadap proses keputusan pembelian konsumen Zenbu PVJ baik secara bersama-sama dan parsial.

\section{TINJAUAN PUSTAKA}

Tinjauan pustaka akan membahas mengenai berbagai variabel dalam penelitian ini.

\section{Kualitas Pelayanan}

Rangkuti (2006) mengatakan bahwa kualitas jasa/pelayanan dipengaruhi oleh dua hal, yaitu jasa yang dirasakan (perceived service) dan jasa yang diharapkan (expected service). Bila perceived service yang dirasakan dibawah expected service, maka pelanggan menjadi tidak tertarik pada penyedia jasa. Tetapi bila perceived service yang dirasakan melebihi expected service, maka kemungkinan pelanggan akan kembali menggunakan layanan dari penyedia layanan tersebut. Tingkat kualitas jasa hanya dapat diukur dari sudut pandang dan penilaian pelanggan.

Dari penelitian Zeithaml,Parasuraman\& Berry (1985) didapatkan lima dimensi dasar yang digunakan konsumen untuk menilai kualitas jasa. Dimensi dasar tersebut adalah sebagai berikut.

1. Reliability (Keandalan)

Keandalan adalah kemampuan perusahaan untuk memenuhi janji pelayanan secara tepat, yakni dikerjakan dengan baik dan diselesaikan dengan hasil yang sama tanpa adanya kesalahan.

2. Responsiveness (Ketanggapan)

Ketanggapan adalah kemauan perusahaan untuk membantu pelanggan dengan menyediakan pelayanan yang tepat waktu, tanggap terhadap kebutuhan pelanggan, fleksibel, berusaha untuk memberikan lebih dari standarnya, memberikan perhatian dan keinginan untuk membantu dan menyelesaikan masalah.

3. Assurance (Jaminan)

Jaminan adalah kemampuan karyawan dan perusahaan untuk memberikan pengetahuan, bersikan ramah dan dapat diberikan kepercayaan serta dapat menjaga rahasia.

4. Emphaty (Empati)

Empati adalah sifat perusahaan untuk memperhatikan dan memberikan pelayanan yang berisfat individu kepada pelanggan.

5. Tangibles (Keberwujudan)

Keberwujudan adalah penampilan dari fasilitas fisik, peralatan, penampilan karyawan dan materi komunikasi.

\section{Kualitas Produk}

Menurut West, Wood, \& Harger (2006), Gaman \& Sherrington (1996), dan Jones (2000) yang dikutip oleh Margaretha (2012) secara garis besar faktor-faktor yang mempengaruhi kualitas makanan adalah sebagai berikut:

a. Warna

Warna dari bahan-bahan makanan harus dikombinasikan sedemikian rupa supaya tidak terlihat pucat atau warnanya tidak serasi. Kombinasi warna sangat membantu dalam selera makan konsumen.

b. Penampilan

Makanan harus baik dilihat saat berada di piring, dimana hal tersebut adalah suatu faktor yang penting. Kesegaran dan kebersihan dari makanan yang disajikan adalah contoh penting yang akan mempengaruhi penampilan makanan baik atau tidak untuk dinikmati.

c. Porsi

Dalam setiap penyajian makanan sudah ditentukan porsi standarnya yang disebut standard portion size. Standard portion size didefinisikan sebagai kuantitas sajian yang harus disajikan setiap kali sajain tersebut dipesan. Manajemen dianjurkan untuk membuat standard portion size secara jelas, misalnya berapa gram daging yang harus disajikan dalam sebuah porsi makanan.

d. Bentuk

Bentuk makanan memainkan peranan penting dalam daya tarik mata. Bentuk makanan yang menarik bisa diperoleh lewat cara pemotongan bahan makanan yang bervariasi, misalnya wortel yang dipotong dengan bentuk potongan dadu digabungkan dengan selada yang dipotong chiffonade yang merupakan potongan yang tidak beraturan pada sayuran.

e. Temperatur

Konsumen menyukai variasi temperatur yang didapatkan dari makanan satu dengan lainnya. Temperatur juga bisa mempengaruhi rasa, misalnya rasa manis pada sebuah makanan akan lebih terasa saat makanan tersebut masih hangat, sementara rasa asin pada sup akan kurang terasa pada saat sup masih panas.

f. Tekstur

Ada banyak tekstur makanan antara lain halus atau tidak, cair atau padat, keras atau lembut, kering atau lembab. Tingkat tipis dan halus serta bentuk makanan dapat dirasakan lewat tekanan dan gerakan dari reseptor di mulut. 
g. Aroma

Aroma adalah reaksi dari makanan yang akan mempengaruhi konsumen sebelum konsumen menikmati makanan, konsumen dapat mencium makanan tersebut.

h. Tingkat kematangan

Tingkat kematangan makanan akan mempengaruhi tekstur dari makanan. Misalnya wortel yang direbus cukup akan menjadi lunak daripada wortel yang direbus lebih cepat. Untuk makanan tertentu seperti steak setiap orang memiliki selera sendirisendiri tentang tingkat kematangan steak.

i. Rasa

Titik perasa dari lidah adalah kemampuan mendeteksi dasar yaitu manis, asam, asin, pahit. Dalam makanan tertentu empat rasa ini digabungkan sehingga menjadi satu rasa yang unik dan menarik untuk dinikmati.

\section{Store Atmosphere}

Utami (2007) mengatakan bahwa store atmosphere adalah desain lingkungan dari segi komunikasi visual, pencahayaan, warna, musi, dan wangi-wangian untuk merangsang respon emosional dan persepsi pelanggan dan mempengaruhi pelanggan dalam membeli barang.

Berman \& Evan (2001) menjelaskan suasana toko memiliki empat elemen.

1. Exterior

Karakteristik eksterior dapat memberikan pengaruh yang kuat pada suatu toko sehingga harus direncanakan dengan matang. Kombinasi dari eksterior dapat membuat bagian luar toko terlihat unik dan menarik sehingga dapat mengundang orang untuk datang ke toko.

2. General Interior

Penataan Interior umum adalah hal yang penting Karena posisi ini berperan sebagai factor penentu pengambilan keputusan pembelian sehingga akan mempengaruhi penjualan. Penataan yang baik adalah penataan yang menarik perhatian pengunjung dan mempermudah mereka untuk mengamati, memeriksa dan memilih barang dan akhirnya melakukan pembelian.

3. Store Layout

Penataan toko adalah elemen yang penting Karena dengan melakukan penataan toko yang benar, perusahaan dapat mendapatkan perilaku konsumen yang diharapkan. Penataan toko juga dapat mengundang pengunjung masuk atau malah menyebabkan pengunjung menjauhi toko tersebut setelah melihat bagian dalam toko melalui jendela atau pintu masuk. Penataan toko yang baik dapat membuat pelanggan datang dan betah untuk berada lama di dalam toko dan berkeliling sehingga kemungkinan pelanggan untuk melakukan pembelian menjadi lebih besar dan dapat berbelanja dengan kuantitas yang lebih banyak.

\section{Interior (Point of Purchase) Display}

Setiap jenis titik display pembelian menyediakan informasi, menambah suasana toko dan mempromosikan produk kepada pelanggan. Tujuan utamanya untuk meningkatkan penjualan dan laba dari toko tersebut.

\section{E-WOM}

Kietzmann \& Canhoto (2013) mengatakan bahwa $e-W O M$ adalah pernyataan berdasarkan pengalaman positif, netral, atau negatif yang dibuat oleh calon konsumen, konsumen, atau mantan konsumen mengenai suatu produk, layanan, merek atau perusahaan yang dibuat dan disebarkan lewat media Internet. Pada penelitiannya, Goyette et al. (2010) membagi $e$ WOM dalam tiga dimensi:

\section{a. Intensity}

Intensity (intensitas) dalam e-WOM adalah banyaknya pendapat yang ditulis oleh konsumen dalam sebuah situs jejaring sosial. Penelitian yang dilakukan oleh Goyette et al. (2010) membagi indikator dari intensity sebagai berikut.

1) Frekuensi mengakses informasi dari situs jejaring sosial.

2) Frekuensi interaksi dengan pengguna situs jejaring sosial.

3) Banyaknya ulasan yang ditulis oleh pengguna situs jejaring sosial.

\section{b. Valence of Opinion}

Valence of opinion adalah pendapat konsumen baik positif atau negatif mengenai produk, jasa dan brand. Valence of opinion memiliki dua sifat yaitu negatif dan positif. Valence of opinion meliputi:

1) Komentar positif dari pengguna situs jejaring sosial, dan

2) Rekomendasi dari pengguna situs jejaring sosial.

\section{c. Content}

Content adalah isi informasi dari situs jejaring sosial berkaitan dengan produk dan jasa. Indikator dari content meliputi:

1) Informasi variasi produk,

2) Informasi kualitas produk, dan

3) Informasi mengenai harga yang ditawarkan. 
Peter \& Olson (2013) menjelaskan keputusan pembelian adalah proses terintegritas yang dilakukan untuk menggabungkan pengetahuan dengan tujuan mengevaluasi beberapa alternatif dan memilih salah satu, sehingga keputusan pembelian dapat diartikan sebagai penentuan pilihan oleh konsumen dari beberapa pilihan yang ada demi memenuhi kebutuhannya.

Kotler \& Keller (2013) menjelaskan proses keputusan pembelian merupakan keputusan konsumen atas berbagai merek yang ada dalam kumpulan pilihan dan dilakukan dalam lima tahap yang digambarkan dalam gambar di bawah ini.

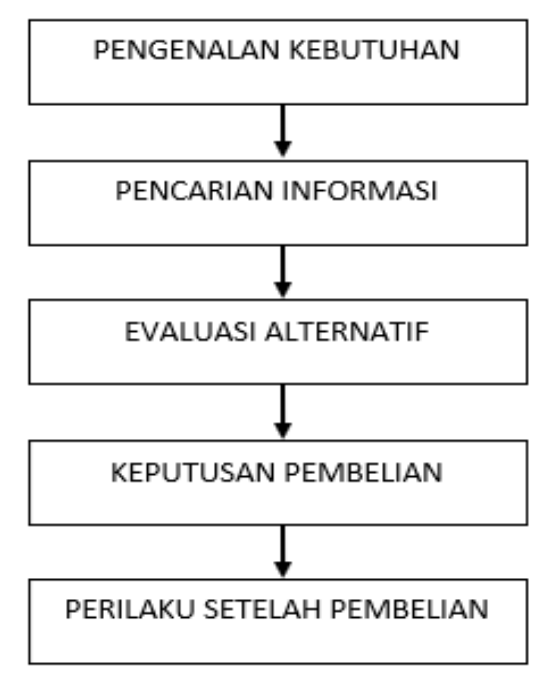

\section{Gambar 2 Five Stages Model of Consumer Buying Process}

Sumber: Kotler \& Keller (2013)

\section{RERANGKA PEMIKIRAN}

Kotler \& Keller (2013) mengatakan agar dapat tetap bertahan di tengah persaingan dan ketidakpastian, setiap perusahaan dituntut untuk berkembang dan meraih competitive advantage dan salah satunya dengan menerapkan konsep pemasaran modern yang berorientasi pasar. Campbell \& Smith (1970; dalam Longart, 2008) mengemukakan bahwa makanan, atmosfer dan pelayanan adalah elemen kunci yang memperluas daya tarik dari pengalaman bersantap dalam suatu restoran. Lewis \& Chambers (2000) menemukan bahwa saat membuat keputusan untuk bersantap dalam suatu restoran melibatkan risiko yang cukup besar dan akhirnya akan membawa konsumen menjadi tergantung pada pengaruh dari $e-W O M$.
Dapat dilihat bahwa dalam industri kuliner, para pelakunya (restoran) perlu memperhatikan kualitas pelayanan, kualitas makanan (produk) dan atmosfer restoran mereka agar dapat menarik konsumen. Restoran juga perlu memikirkan bagaimana mereka dapat menyebarkan informasi mengenai restoran mereka guna menarik minat calon konsumen untuk berkunjung ke restoran mereka. Salah satunya adalah dengan menggunakan media $e$ WOM yang merupakan media pemasaran yang relatif murah dan dapat tersebar luas dengan mudah dan cepat.

Penelitian terdahulu yang ditulis oleh Petricia \& Syahputra (2015) menunjukkan bahwa kualitas produk berpengaruh secara positif dan signifikan terhadap proses keputusan pembelian dan kualitas pelayanan berpengaruh secara positif dan signifikan terhadap proses keputusan pembelian. Penelitian ini dilakukan terhadap suatu kedai kopi di Kota Bandung. Hasil penelitian dari Dian \& Artanti (2013) menunjukkan terdapat pengaruh antara atmosfer restoran terhadap keputusan pembelian produk Starbucks di kedai kopi Starbucks Surabaya Town Square.

Hasil penelitian dari variabel kualitas produk, kualitas pelayanan, dan store atmosphere dari penelitian terdahulu belum tentu mendapatkan hasil yang sama pada penelitian lain dikarenakan perbedaan lokasi, jenis produk yang ditawarkan maupun faktor lainnya. Perbedaan ini juga terdapat dalam penelitian yang ditulis karena objek penelitian yang diteliti merupakan suatu restoran yang berada di dalam pusat perbelanjaan dan produk yang ditawarkan merupakan produk makanan Jepang dan bukan produk kopi. Selain itu kualitas pelayanan yang diberikan tentunya akan berbeda antara satu restoran dengan restoran yang lainnya dikarenakan perbedaan pendekatan, training dan faktor lainnya.

Penelitian dari Firdaus \& Abdullah (2017) menunjukkan terdapat pengaruh yang signifikan dari $e$-WOM terhadap keputusan pembelian tamu restoran di Bandung Utara. Hasil ini juga belum tentu menunjukkan hasil yang sama dikarenakan perbedaan strategi pemasaran dan teknik yang digunakan dalam mengoptimalkan media $e$-WOM. 


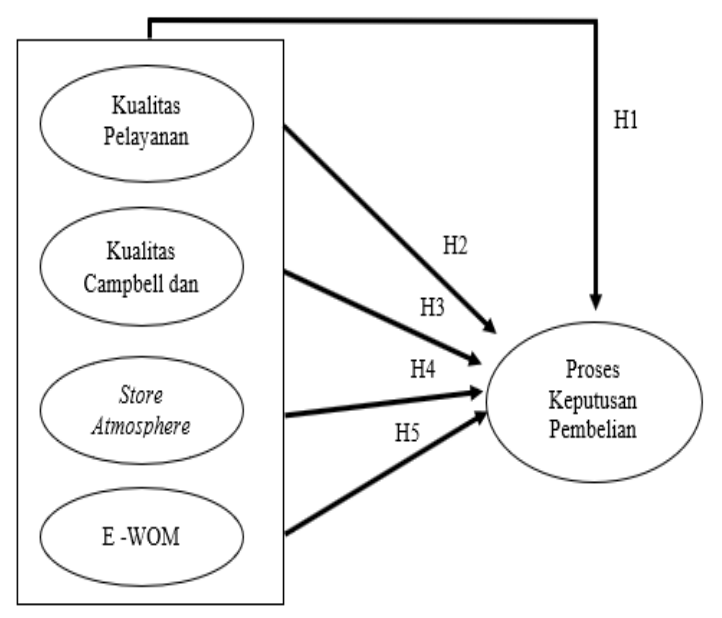

Gambar 3 Model Penelitian

Sumber Diolah dari berbagai sumber

\section{HIPOTESIS PENELITIAN}

Hipotesis adalah dugaan sementara yang kebenarannya masih harus dilakukan pengujian. Dugaan sementara dalam penelitian ini adalah sebagai berikut.

H1: Terdapat pengaruh kualitas pelayanan, kualitas produk, store atmosphere, dan e-WOM Zenbu PVJ terhadap proses keputusan pembelian $\mathrm{H} 2$ : Terdapat pengaruh kualitas pelayanan Zenbu PVJ terhadap proses keputusan pembelian H3: Terdapat pengaruh kualitas produk Zenbu PVJ terhadap proses keputusan pembelian H4: Terdapat pengaruh store atmosphere Zenbu PVJ terhadap proses keputusan pembelian H5: Terdapat pengaruh $e-W O M$ Zenbu PVJ terhadap proses keputusan pembelian

\section{METODE PENELITIAN}

Berdasarkan permasalahan dan tujuan penelitian, maka penelitian ini bersifat deskriptif dan verifikatif dengan pendekatan kuantitatif. Menurut Sugiyono (2009) metode deskriptif adalah penelitian yang dilakukan untuk menggambarkan variabel mandiri, baik pada satu variabel atau lebih (variabel yang berdiri sendiri) tanpa membuat perbandingan variabel tesebut dengan variabel lain. Sedangkan metode verifikatif menurut Sugiyono (2009) adalah penelitian yang dilakukan terhadap suatu populasi atau sampel tertentu dengan tujuan untuk menguji hipotesis yang telah ditetapkan.

Metode penelitian yang digunakan dalam penelitian ini adalah metode kuantitatif. Sugiyono (2009) menjelaskan metode kuantitatif adalah metode penelitian yang berlandaskan pada filsafat positivisme, digunakan untuk meneliti populasi atau sampel tertentu. Pengumpulan data menggunakan instrumen penelitian, analisis data bersifat kuantitatif atau statistik dengan tujuan untuk menguji hipotesis yang telah ditentukan.

\section{Populasi}

Sugiyono (2009) menjelaskan pengertian populasi adalah wilayah generalisasi yang terdiri atas obyek/subyek yang mempunyai kualitas dan karakteristik tertentu yang ditetapkan oleh peneliti untuk dipelajari dan kemudian ditarik simpulannya. Dalam penelitian ini, populasi yang diambil adalah seluruh konsumen yang sudah pernah berkunjung dan bersantap di Zenbu PVJ Bandung.

\section{SAMPEL}

Pengertian sampel menurut Sugiyono (2009) adalah bagian dari jumlah dan karakteristik yang dimiliki oleh populasi tersebut. Penarikan sampel dilakukan dengan menggunakan teknik penarikan non-probability sampling. Pengertian non-probability sampling menurut Sugiyono (2009) adalah teknik pengambilan sampel yang tidak memberi peluang atau kesempatan sama bagi setiap unsur atau anggota populasi untuk dipilih menjadi sampel. Pada penelitian ini populasi yang diambil berukuran besar dan jumlahnya tidak diketahui secara pasti.

Dalam penentuan sampel jika populasinya besar dan jumlahnya tidak diketahui maka menurut Rao (2006) digunakan rumus sebagai berikut.

$$
\begin{gathered}
n=\frac{\mathrm{Z}^{2}}{4(m o e)^{2}} \\
n=\frac{1.96^{2}}{4(0.1)^{2}}=96
\end{gathered}
$$

\section{Keterangan:}

$n=$ Jumlah sampel.

$\mathrm{Z}=$ Nilai $Z$ Score dari nilai tingkat kepercayaan $95 \%$ adalah sebesar 1.96

moe $=$ Margin of error atau kesalahan maksimum yang bisa ditoleransi, biasanya 10 persen.

Dari perhitungan di atas, maka dapat diketahui bahwa jumlah sampel yang digunakan dalam penelitian ini sebanyak 96 orang. Untuk memudahkan penelitian, maka peneliti mengambil sampel sebesar 100 responden.

Teknik non-probability sampling yang digunakan adalah teknik purposive sampling. Menurut Suliyanto (2009), purposive sampling adalah pengambilan sample tidak acak yang mendasarkan pada karakteristik populasi dalam jumlah yang telah ditetapkan dengan tujuan 
meningkatkan derajat keterwakilan masingmasing kelompok dalam populasi. Penelitian ini mengambil konsumen Zenbu PVJ yang pernah berkunjung dan melakukan santap di restoran Zenbu PVJ dalam kurun waktu dua tahun terakhir terhitung sejak Agustus 2015 dan dimaksudkan agar sampel yang didapat merupakan konsumen Zenbu PVJ yang telah merasakan store atmosphere setelah adanya renovasi dan perubahan layout interior terakhir.

\section{Definisi Operasional Variabel}

Menurut Sugiyono (2009), definisi operasional variabel adalah batasan pengertian tentang variabel yang diteliti yang di dalamnya adalah mencerminkan indikator-indikator yang akan digunakan untuk mengukur indikator-indikator yang bersangkutan. Berikut adalah definisi operasional variabel dalam penelitian ini.

Tabel 1 Definisi Operasional Variabel

\begin{tabular}{|c|c|c|c|}
\hline $\begin{array}{l}\text { Variabel } \\
\text { Penelitian }\end{array}$ & Dimensi & Konsep & Skala \\
\hline \multirow[t]{5}{*}{$\begin{array}{l}\text { Kualitas } \\
\text { Pelayanan } \\
\text { (X1) }\end{array}$} & Tangible & $\begin{array}{l}\text { Bukti fisik dari } \\
\text { pelayanan, biasa } \\
\text { berupa fasilitas fisik, } \\
\text { peralatan yang } \\
\text { digunakan dan } \\
\text { representasi fisik } \\
\text { dari jasa }\end{array}$ & Interval \\
\hline & Reliability & $\begin{array}{l}\text { Kemampuan } \\
\text { memberikan } \\
\text { pelayanan yang } \\
\text { dijanjikan dengan } \\
\text { segera, akurat dan } \\
\text { memuaskan }\end{array}$ & \\
\hline & Responsiveness & $\begin{array}{l}\text { Keinginan para staff } \\
\text { untuk membantu } \\
\text { para konsumen dan } \\
\text { memberikan } \\
\text { pelayanan dengan } \\
\text { tanggap }\end{array}$ & \\
\hline & Assurance & $\begin{array}{l}\text { Pengetahuan, } \\
\text { kemampuan, } \\
\text { kesopanan dan sifat } \\
\text { dapat dipercaya yang } \\
\text { dimiliki para staff }\end{array}$ & \\
\hline & Emphaty & $\begin{array}{l}\text { Meliputi kemudahan } \\
\text { dalam melakukan } \\
\text { hubungan, } \\
\text { komunikasi yang } \\
\text { baik, perhatian } \\
\text { pribadi dan } \\
\text { memahami } \\
\text { kebutuhan para } \\
\text { konsumen }\end{array}$ & \\
\hline \multirow[t]{3}{*}{$\begin{array}{l}\text { Kualitas } \\
\text { Produk } \\
\text { (X2) }\end{array}$} & Warna & $\begin{array}{l}\text { Warna dari bahan } \\
\text { makanan harus } \\
\text { dikombinasikan } \\
\text { sedemikian rupa }\end{array}$ & Interval \\
\hline & Penampilan & $\begin{array}{l}\text { Makanan harus baik } \\
\text { dilihat saat berada di } \\
\text { piring }\end{array}$ & \\
\hline & Porsi & $\begin{array}{l}\text { Dalam setiap } \\
\text { penyajian makanan } \\
\text { sudah ditentukan } \\
\text { porsi standarnya } \\
\text { yang disebut } \\
\text { standard portion }\end{array}$ & \\
\hline
\end{tabular}

size.

$\begin{array}{ll}\text { Bentuk } & \text { Bentuk makanan } \\ & \text { memainkan perana } \\ \text { penting dalam daya } & \text { tarik mata. }\end{array}$

Aroma

Aroma adalah reaksi dari makanan yang akan mempengaruhi konsumen sebelum konsumen menikmati makanan Konsumen menyukai variasi temperatur yang didapatkan dari makanan satu dengan lainnya.

Tekstur Ada banyak tekstur makanan antara lain halus atau tidak, cair atau padat, keras atau lembut, kering atau lembab.

Tingkat kematangan makanan akan mempengaruhi tekstur dari makanan.

Titik perasa dari lidah adalah kemampuan mendeteksi dasar yaitu manis, asam, asin, pahit. Dalam makanan tertentu empat rasa ini digabungkan sehingga menjadi satu rasa yang unik dan menarik untuk dinikmati.

$\begin{array}{ll}\text { Store } & \text { Bagian } \\ \text { Atmosphere } & \text { Luar } \\ \text { (X3) } & \text { Restoran } \\ & \text { (Exterior) }\end{array}$

Karakteristik Interval eksterior dapat memberikan pengaruh yang kuat pada suatu toko sehingga harus direncanakan dengan matang.

Bagian

Dalam

Restoran

(General Interior)

Berperan sebagai faktor penentu pengambilan keputusan pembelian sehingga akan mempengaruhi penjualan. 


\begin{tabular}{|c|c|c|c|}
\hline & $\begin{array}{l}\text { Tata Letak } \\
\text { Restoran } \\
\text { (Store } \\
\text { Layout) }\end{array}$ & $\begin{array}{l}\text { Penataan toko } \\
\text { adalah elemen } \\
\text { yang penting } \\
\text { karena dengan } \\
\text { melakukan } \\
\text { penataan toko } \\
\text { yang benar, } \\
\text { perusahaan } \\
\text { dapat } \\
\text { mendapatkan } \\
\text { perilaku } \\
\text { konsumen yang } \\
\text { diharapkan. }\end{array}$ & \\
\hline & $\begin{array}{l}\text { Pemajangan } \\
\text { Informasi } \\
\text { (Interior } \\
\text { Displays) }\end{array}$ & $\begin{array}{l}\text { Setiap jenis titik } \\
\text { display } \\
\text { pembelian } \\
\text { menyediakan } \\
\text { informasi, } \\
\text { menambah } \\
\text { suasana toko } \\
\text { dan } \\
\text { mempromosikan } \\
\text { produk kepada } \\
\text { pelanggan. }\end{array}$ & \\
\hline $\begin{array}{l}\text { E - WOM } \\
(\mathrm{X} 4)\end{array}$ & Intensity & $\begin{array}{l}\text { Banyaknya } \\
\text { pendapat yang } \\
\text { ditulis oleh } \\
\text { konsumen } \\
\text { dalam sebuah } \\
\text { situs jejaring } \\
\text { sosial. }\end{array}$ & Interval \\
\hline & $\begin{array}{l}\text { Valence of } \\
\text { Opinion }\end{array}$ & $\begin{array}{l}\text { Pendapat } \\
\text { konsumen baik } \\
\text { positif atau } \\
\text { negatif } \\
\text { mengenai } \\
\text { produk, jasa dan } \\
\text { brand. }\end{array}$ & \\
\hline & Content & $\begin{array}{l}\text { Isi informasi } \\
\text { dari situs } \\
\text { jejaring sosial } \\
\text { berkaitan } \\
\text { dengan produk } \\
\text { dan jasa }\end{array}$ & \\
\hline \multirow[t]{3}{*}{$\begin{array}{l}\text { Proses } \\
\text { Keputusan } \\
\text { Pembelian } \\
\text { (Y) }\end{array}$} & $\begin{array}{l}\text { Pengenalan } \\
\text { Masalah }\end{array}$ & $\begin{array}{l}\text { Pembeli } \\
\text { mengetahui } \\
\text { masalah apa } \\
\text { yang dihadapi } \\
\text { atau adanya } \\
\text { kebutuhan. }\end{array}$ & Interval \\
\hline & $\begin{array}{l}\text { Pencarian } \\
\text { Informasi }\end{array}$ & $\begin{array}{l}\text { Pembeli yang } \\
\text { tertarik lalu } \\
\text { mulai mencari } \\
\text { informasi atau } \\
\text { juga tidak. }\end{array}$ & \\
\hline & $\begin{array}{l}\text { Evaluasi } \\
\text { Alternatif }\end{array}$ & $\begin{array}{l}\text { Pembeli } \\
\text { memproses } \\
\text { informasi yang } \\
\text { didapatkan } \\
\text { untuk dievaluasi } \\
\text { merek - merek } \\
\text { yang ada dalam } \\
\text { alternatf } \\
\text { pilihannya. }\end{array}$ & \\
\hline
\end{tabular}

$\begin{array}{ll}\text { Keputusan } & \text { Setelah } \\ \text { Pembelian } & \text { menetapkan } \\ & \text { pilihan, pembeli } \\ \text { akan memilih } & \text { suatu merek dan } \\ & \text { kemudian } \\ \text { melakukan } & \text { pembelian. } \\ & \text { Setelah } \\ & \text { pembelian } \\ \text { Perilaku } & \text { dilakukan, maka } \\ \text { Pasca } & \text { akan berlanjut } \\ \text { Pembelian } & \text { pada fase pasca } \\ & \text { pembelian. } \\ & \text { Pembeli akan } \\ & \text { mengalami } \\ & \text { suatu tingkat } \\ & \text { kepuasan atau } \\ & \text { ketidakpuasan } \\ & \text { di mana } \\ & \text { pengalaman } \\ & \text { tersebut akan } \\ & \text { mempengaruhi } \\ & \text { tingkah laku } \\ & \text { pembeli } \\ & \text { berikutnya. } \\ & \end{array}$

Sumber: Diolah dari berbagai sumber

\section{PEMBAHASAN HASIL PENELITIAN}

Setelah mendapatkan hasil dari kuesioner, data tersebut kemudian diolah menggunakan SPSS versi 23. Pengolahan data yang dilakukan bertujuan untuk mendapatkan persamaan regresi linear yang akan digunakan dalam pengambilan kesimpulan penelitian.

\section{Uji Validitas}

Uji validitas digunakan untuk mengukur sah atau tidaknya satu kuesioner. Satu kuesioner dinyatakan valid jika pertanyaan pada pertanyaan kuesioner mampu mengungkapkan sesuatu yang akan diukur oleh kuesioner tersebut.

\section{Kualitas Pelayanan}

Tabel 2 Hasil Uji Validitas Kualitas Pelayanan

\begin{tabular}{cccc}
\hline No. & $\begin{array}{c}\text { Nilai } \mathrm{r} \\
\text { Tabel }\end{array}$ & $\begin{array}{c}\text { Nilai } \mathrm{r} \\
\text { Hitung }\end{array}$ & Keterangan \\
\hline 1 & 0.1966 & 0.286 & Valid \\
2 & 0.1966 & 0.391 & Valid \\
3 & 0.1966 & 0.362 & Valid \\
4 & 0.1966 & 0.55 & Valid \\
5 & 0.1966 & 0.456 & Valid \\
6 & 0.1966 & 0.657 & Valid \\
7 & 0.1966 & 0.499 & Valid \\
8 & 0.1966 & 0.496 & Valid
\end{tabular}




\begin{tabular}{cccccccc}
9 & 0.1966 & 0.524 & Valid & 11 & 0.1966 & 0.619 & Valid \\
10 & 0.1966 & 0.38 & Valid & 12 & 0.1966 & 0.534 & Valid \\
11 & 0.1966 & 0.551 & Valid & 13 & 0.1966 & 0.46 & Valid \\
\cline { 5 - 8 } 12 & 0.1966 & 0.584 & Valid & Sumber: Hasil pengolahan SPSS versi 23 &
\end{tabular}

Sumber: Hasil pengolahan SPSS versi 23

Hasil olah data mennyatakan corrected item-total correlation pada setiap pertanyaan bernilai lebih besar dari nilai $r$ tabel sebesar 0,1966. Maka setiap pertanyaan mengenai kualitas pelayanan dalam penelitian ini dinyatakan valid.

\section{Kualitas Produk}

Tabel 3 Hasil Uji Validitas Kualitas Produk

\begin{tabular}{cccc}
\hline No. & $\begin{array}{c}\text { Nilai } \mathrm{r} \\
\text { Tabel }\end{array}$ & $\begin{array}{c}\text { Nilai } \mathrm{r} \\
\text { Hitung }\end{array}$ & Keterangan \\
\hline 1 & 0.1966 & 0.55 & Valid \\
2 & 0.1966 & 0.491 & Valid \\
3 & 0.1966 & 0.562 & Valid \\
4 & 0.1966 & 0.387 & Valid \\
5 & 0.1966 & 0.716 & Valid \\
6 & 0.1966 & 0.6 & Valid \\
7 & 0.1966 & 0.511 & Valid \\
8 & 0.1966 & 0.632 & Valid \\
9 & 0.1966 & 0.561 & Valid \\
10 & 0.1966 & 0.593 & Valid \\
\hline
\end{tabular}

Sumber: Hasil pengolahan SPSS versi 23

Hasil olah data menjunjukkan nilai corrected item-total correlation pada setiap pertanyaan bernilai lebih besar dari nilai $r$ tabel sebesar 0,1966. Maka setiap pertanyaan mengenai kualitas produk dalam penelitian ini dinyatakan valid.

\section{Store Atmosphere}

Tabel 4 Hasil Uji Validitas Store Atmosphere

\begin{tabular}{cccc}
\hline No. & $\begin{array}{c}\text { Nilai r } \\
\text { Tabel }\end{array}$ & $\begin{array}{c}\text { Nilai } \mathrm{r} \\
\text { Hitung }\end{array}$ & Keterangan \\
\hline 1 & 0.1966 & 0.436 & Valid \\
2 & 0.1966 & 0.482 & Valid \\
3 & 0.1966 & 0.31 & Valid \\
4 & 0.1966 & 0.404 & Valid \\
5 & 0.1966 & 0.43 & Valid \\
6 & 0.1966 & 0.541 & Valid \\
7 & 0.1966 & 0.624 & Valid \\
8 & 0.1966 & 0.559 & Valid \\
9 & 0.1966 & 0.567 & Valid \\
10 & 0.1966 & 0.527 & Valid
\end{tabular}

Hasil uji validitas menunjukkan nilai corrected item-total correlation pada setiap pertanyaan bernilai lebih besar dari nilai $r$ tabel sebesar 0,1966. Maka setiap pertanyaan mengenai store atmospheredalam penelitian ini dinyatakan valid.

\section{4. $e-W O M$}

Tabel 5 Hasil Uji Validitas $e$-WOM

\begin{tabular}{cccc}
\hline No. & $\begin{array}{c}\text { Nilai } \mathrm{r} \\
\text { Tabel }\end{array}$ & $\begin{array}{c}\text { Nilai } \mathrm{r} \\
\text { Hitung }\end{array}$ & Keterangan \\
\hline 1 & 0.1966 & 0.323 & Valid \\
2 & 0.1966 & 0.68 & Valid \\
3 & 0.1966 & 0.669 & Valid \\
4 & 0.1966 & 0.679 & Valid \\
5 & 0.1966 & 0.761 & Valid \\
6 & 0.1966 & 0.746 & Valid \\
7 & 0.1966 & 0.708 & Valid \\
\hline
\end{tabular}

Sumber: Hasil pengolahan SPSS versi 23

Dari 7 butir pertanyaan yang diajukan, hasil uji validitas menjunjukkan nilai corrected item-total correlation pada setiap pertanyaan bernilai lebih besar dari nilai $\mathrm{r}$ tabel sebesar 0,1966. Maka setiap pertanyaan mengenai $e-W O M$ dalam penelitian ini dinyatakan valid.

\section{Proses Keputusan Pembelian}

Tabel 6 Hasil Uji Validitas Proses Keputusan Pembelian

\begin{tabular}{cccc}
\hline No. & $\begin{array}{c}\text { Nilai } \mathrm{r} \\
\text { Tabel }\end{array}$ & $\begin{array}{c}\text { Nilai } \mathrm{r} \\
\text { Hitung }\end{array}$ & Keterangan \\
\hline 1 & 0.1966 & 0.38 & Valid \\
2 & 0.1966 & 0.466 & Valid \\
3 & 0.1966 & 0.515 & Valid \\
4 & 0.1966 & 0.512 & Valid \\
5 & 0.1966 & 0.498 & Valid \\
6 & 0.1966 & 0.483 & Valid \\
7 & 0.1966 & 0.557 & Valid \\
8 & 0.1966 & 0.373 & Valid \\
\hline
\end{tabular}

Sumber: Hasil pengolahan SPSS versi 23

Hasil uji validitas menjunjukkan nilai corrected item-total correlation pada setiap pertanyaan bernilai lebih besar dari nilai $r$ tabel sebesar 0,1966 . Maka setiap pertanyaan mengenai proses 
keputusan pembelian dalam penelitian ini dinyatakan valid.

\section{Uji Reliabilitas}

Reliabilitas adalah alat untuk mengukur suatu kuesioner yang merupakan indikator dari suatu variabel. Suatu kuesioner dikatakan reliabel atau handal jika jawaban pertanyaan adalah konsisten atau stabil dari waktu ke waktu.

Tabel 7 Hasil Uji Reliabilitas Variabel Penelitian

\begin{tabular}{ccc}
\hline Variabel & $\begin{array}{c}\text { Koefisien } \\
\text { Reliabilitas }\end{array}$ & Keterangan \\
\hline $\begin{array}{c}\text { Kualitas } \\
\text { Pelayanan }\end{array}$ & 0.825 & Reliabel \\
Kualitas Produk & 0.849 & Reliabel \\
$\begin{array}{c}\text { Store Atmosphere } \\
\text { Electronic Word } \\
\text { of Mouth }\end{array}$ & 0.837 & Reliabel \\
$\begin{array}{c}\text { Proses Keputusan } \\
\text { Pembelian }\end{array}$ & 0.867 & Reliabel \\
\hline Sumber: Hasil pengol & Reliabel \\
\hline
\end{tabular}

Sumber: Hasil pengolahan SPSS versi 23

Nilai koefisien reliabilitas seluruh variabel variabel kualitas proses keputusan pembelian yang didapat bernilai lebih dari 0,6 atau maka dapat dikatakan bahwa kuesioner semua variabel dinyatakan reliabel.

\section{Uji Asumsi Klasik}

Uji asumsi klasik bertujuan untuk mengetahui kondisi data yang digunakan dalam penelitian. Hal tersebut dilakukan untuk mendapatkan model analisis yang tepat dengan menggunakan uji asumsi klasik yang meliputi uji normalitas, uji multikolinearitas, dan uji heteroskedastisitas.

\section{Uji Normalitas}

Uji normalitas bertujuan untuk mengetahui apakah dalam model regresi, variabel pengganggu atau residual memiliki distribusi normal. Model regresi yang baik adalah memiliki distribusi data normal atau mendekati normal.

\section{Tabel 8 Hasil Uji Normalitas Data}

\begin{tabular}{cc}
\hline Keterangan & Value \\
\hline Asymp. Sig. (2-tailed) & 0.144 \\
\hline \multicolumn{2}{l}{ Sumber: Hasil pengolahan SPSS versi 23}
\end{tabular}

Tabel pengolahan data di atas menunjukkan hasil asymptotic significance (2-tailed) sebesar 0,144 atau lebih besar dari 0,05 ( $\alpha)$ maka dapat disimpulkan bahwa distribusi data dalam penelitian ini bersifat normal.

\section{Uji Multikolinearitas}

Uji multikolinearitas bertujuan untuk menguji apakah model regresi ditemukan adanya korelasi antar variabel independen.

Tabel 9 Hasil Uji Multikolinearitas

\begin{tabular}{ccc}
\hline Variabel & Tolerance & VIF \\
\hline Kualitas & 0.418 & 2.393 \\
Pelayanan & 0.477 & 2.096 \\
Kualitas Produk & 0.574 & 1.742 \\
$\begin{array}{c}\text { Store Atmosphere } \\
\text { Electronic Word } \\
\text { of Mouth }\end{array}$ & 0.756 & 1.323 \\
\hline
\end{tabular}

Sumber: Hasil pengolahan SPSS versi 23

Hasil pengolahan data menunjukkan seluruh nilai Tolerance lebih besar daripada 0,1 dan seluruh nilai VIF lebih kecil daripada 10. Maka dapat disimpulkan bahwa model regresi ini tidak menunjukkan adanya masalah multikolinearitas.

\section{Uji Heteroskedastisitas}

Uji heteroskedastisitas bertujuan untuk menguji apakah dalam model regresi terjadi ketidaksamaan varians dari residual satu pengamatan ke pengamatan yang lain.

\section{Tabel 10 Hasil Uji Heteroskedastisitas}

\begin{tabular}{cc}
\hline Variabel & Assym Sig \\
\hline Kualitas & 0.523 \\
Pelayanan & 0.63 \\
Kualitas Produk & 0.74 \\
$\begin{array}{c}\text { Store Atmosphere } \\
\text { Electronic Word } \\
\text { of Mouth }\end{array}$ & 0.942 \\
\hline
\end{tabular}

Sumber: Hasil pengolahan SPSS versi 23

Hasil pengolahan data yang telah dilakukan pada Tabel 10 uji heteroskedastisitas, dapat dilihat bahwa seluruh nilai Sig. lebih besar daripada 0,05 . Maka dapat disimpulkan bahwa tidak terjadi masalah heteroskedastisitas dalam model regresi ini.

\section{Uji t (Parsial)}

Uji t pada dasarnya menunjukkan seberapa jauh pengaruh satu variabel penjelasan atau independen secara individual dalam menerangkan variasi variabel dependen. 
Tabel 11 Tabel Hasil Uji t (Parsial)

\begin{tabular}{cccccc} 
Model & $\begin{array}{c}\text { Unstandardized } \\
\text { Coefficients }\end{array}$ & $\begin{array}{c}\text { Standardized } \\
\text { Coefficients }\end{array}$ & & & \\
\hline & $\mathrm{B}$ & Std. Error & Beta & $\mathrm{t}$ & Sig. \\
\cline { 2 - 6 } Constant & 7.743 & 3.611 & & 2.144 & 0.035 \\
$\begin{array}{c}\text { Kualitas } \\
\text { Pelayanan }\end{array}$ & 0.231 & 0.112 & 0.261 & 2.057 & 0.042 \\
$\begin{array}{c}\text { Kualitas } \\
\text { Produk }\end{array}$ & 0.08 & 0.112 & 0.085 & 0.713 & 0.478 \\
$\begin{array}{c}\text { Store } \\
\text { Atmosphere }\end{array}$ & 0.032 & 0.079 & 0.044 & 0.402 & 0.689 \\
$\begin{array}{c}\text { Electronic } \\
\text { Word of } \\
\text { Mouth }\end{array}$ & 0.301 & 0.082 & 0.345 & 3.657 & 0 \\
\hline
\end{tabular}

Sumber: Hasil pengolahan SPSS versi 23

Berdasarkan Tabel 11, dapat dilihat bahwa dari keempat variabel bebas, terdapat dua variabel yang dinyatakan berpengaruh yaitu kualitas pelayanan dan $e-W O M$ karena nilai signifikansi kedua variabel tersebut bernilai lebih kecil daripada 0,05 sedangkan nilai signifikansi variabel kualitas produk dan store atmosphere bernilai lebih besar daripada 0,05. Dari hasil regresi tesebut maka dapat disimpulkan hipotesis pada penelitian sebagai berikut.

\section{Pengaruh Kualitas Pelayanan Zenbu PVJ terhadap Proses Keputusan Pembelian}

$\mathrm{H}_{0}$ : Tidak terdapat pengaruh kualitas pelayanan Zenbu PVJ terhadap proses keputusan pembelian.

$\mathrm{H}_{2}$ : Terdapat pengaruh kualitas pelayanan Zenbu PVJ terhadap proses keputusan pembelian.

Berdasarkan Tabel 11, diketahui bahwa $p$-value dari variabel kualitas pelayanan sebesar 0,042 lebih kecil daripada 0,05 maka $\mathrm{H}_{0}$ ditolak dan $\mathrm{H}_{2}$ diterima. Hal tersebut menunjukkan bahwa terdapat pengaruh variabel kualitas pelayanan terhadap proses keputusan pembelian. Hal ini dapat dapat disebabkan karena kualitas pelayanan yang diberikan Zenbu PVJ dapat berbeda dari satu kunjungan dengan kunjungan lainnya. Hasil ini juga sesuai dengan pernyataan dari Griffith (2017) yang mengatakan bahwa konsumen lebih terpengaruh terhadap kualitas pelayanan dibandingkan kualitas produk atau makanannya.

\section{Pengaruh Kualitas Produk Zenbu PVJ terhadap Proses Keputusan Pembelian}

$\mathrm{H}_{0}$ : Tidak terdapat pengaruh kualitas produk Zenbu PVJ terhadap proses keputusan pembelian.

$\mathrm{H}_{3}$ : Terdapat pengaruh kualitas produk Zenbu PVJ terhadap proses keputusan pembelian.
Berdasarkan tabel di atas, diketahui bahwa p-value dari variabel kualitas produk sebesar 0,478 lebih besar daripada 0,05 maka $\mathrm{H}_{0}$ diterima dan $\mathrm{H}_{3}$ ditolak. Hal tersebut menunjukkan bahwa tidak terdapat pengaruh variabel kualitas produk terhadap proses keputusan pembelian. Berdasarkan jawaban responden, sebanyak 53 persen responden sudah pernah berkunjung ke Zenbu PVJ sebanyak dua hingga lima kali dan 23 persen sudah pernah berkunjung lebih dari lima kali sejak Agustus 2015. Hal ini mengakibatkan penilaian responden terpengaruh pengalaman berkunjung mereka yang sebelumnya dan responden sudah mengetahui kualitas produk yang ditawarkan Zenbu PVJ sehingga variabel kualitas produk tidak lagi memberikan pengaruh terhadap proses keputusan pembelian.

Pengaruh Store Atmosphere Zenbu PVJ terhadap Proses Keputusan Pembelian

$\mathrm{H}_{0}$ : Tidak terdapat pengaruh store atmosphere Zenbu PVJ terhadap proses keputusan pembelian.

$\mathrm{H}_{4}$ : Terdapat pengaruh store atmosphere Zenbu PVJ terhadap proses keputusan pembelian.

Berdasarkan Tabel 11, diketahui bahwa p-value dari variabel store atmosphere sebesar 0,689 lebih besar daripada 0,05 maka $\mathrm{H}_{0}$ diterima dan $\mathrm{H}_{4}$ ditolak. Hal tersebut menunjukkan bahwa tidak terdapat pengaruh variabel store atmosphere terhadap proses keputusan pembelian. Hal ini dapat disebabkan karena Zenbu PVJ berada di dalam Mal PVJ di mana kebanyakan restorannya didesain dengan bentuk gedung dan ukuran yang hampir sama sehingga konsumen sudah dapat menduga bagaimana store atmosphere yang akan dirasakan konsumen. Hal ini yang menyebabkan variabel store atmosphere menjadi tidak berpengaruh terhadap proses keputusan pembelian.

\section{Pengaruh E-WOM Zenbu PVJ Terhadap Proses Keputusan Pembelian}

$\mathrm{H}_{0}$ : Tidak terdapat pengaruh $e-W O M$ Zenbu PVJ terhadap proses keputusan pembelian.

$\mathrm{H}_{5}$ : Terdapat pengaruh $e$-WOM Zenbu PVJ terhadap proses keputusan pembelian.

Berdasarkan Tabel 11, diketahui bahwa $p$-value dari variabel $e$-WOM sebesar 0,000 lebih kecil daripada 0,05 maka $\mathrm{H}_{0}$ ditolak dan $\mathrm{H}_{5}$ diterima. Hal tersebut menunjukkan bahwa terdapat pengaruh variabel $e-W O M$ terhadap proses keputusan pembelian. Hal ini dapat disebabkan karena $e$-WOM menjadi salah satu pusat informasi yang paling mudah diakses 
melalui media sosial dan juga memberikan ulasan-ulasan yang jujur dan netral dari berbagai pengguna media sosial yang telah merasakan pengalaman bersantap di Zenbu PVJ. Maka variabel $e-W O M$ menjadi variabel yang berpengaruh terhadap proses keputusan pembelian.

Model regresi merupakan model yang digunakan untuk menganalisis pengaruh dari berbagai variabel independen terhadap satu variabel dependen. Setelah keempat hipotesis di atas disimpulkan, kemudian persamaan regresi linear berganda dari penelitian ini dapat dibuat. Berikut persamaan regresi linear berganda dalam penelitian ini.

$$
\begin{aligned}
& Y=7,743+0,231 X_{1}+0,080 X_{2}+0,032 X_{3}+ \\
& \mathbf{0 , 3 0 1 X _ { 4 } + e}
\end{aligned}
$$

Hasil persamaan di atas menunjukkan bahwa semakin baik kualitas pelayanan dan e-WOM Zenbu PVJ maka akan semakin tinggi juga proses keputusan pembeliannya. Sedangkan kualitas produk dan store atmosphere Zenbu PVJ tetap memberikan pengaruh terhadap proses keputusan pembelian tetapi tidak berdampak secara signifikan

\section{Uji Koefisien Determinasi}

Nilai adjusted $R$ square adalah nilai yang menunjukkan seberapa baik model regresi yang dipakai dalam penelitian.

\section{Tabel 12 Tabel Hasil Pengujian Koefisien} Determinasi

\begin{tabular}{ccccc}
\hline Model & $\mathrm{R}$ & $\begin{array}{c}\mathrm{R} \\
\text { Square }\end{array}$ & $\begin{array}{c}\text { Adjusted } \\
\mathrm{R} \\
\text { Square }\end{array}$ & $\begin{array}{c}\text { Std. } \\
\text { Error of } \\
\text { the } \\
\text { Estimate }\end{array}$ \\
\hline 1 & 0.6000 & 0.359 & 0.332 & 324.049 \\
\hline
\end{tabular}

Sumber: Hasil pengolahan SPSS versi 23

Dari hasil pengujian koefisien determinasi, didapatkan hasil dari adjusted $R$ square di bawah angka 0,5 dan dapat diartikan bahwa variabelvariabel independen pada penelitian ini yaitu kualitas pelayanan, kualitas produk, store atmosphere dan $e$-WOM hanya memberikan sebagian kecil informasi yang dibutuhkan untuk memprediksi variabel dependen yaitu proses keputusan pembelian. Berdasarkan tabel di atas, dapat disimpulkan bahwa variabel independen dalam penelitian ini yaitu kualitas pelayanan, kualitas produk, store atmosphere dan e-WOM hanya berpengaruh sebesar 33,2 persen sedangkan sisanya sebesar 66,8 persen dipengaruhi oleh variabel lain yang tidak diteliti dalam penelitian ini misalnya brand image, customer experience, dan lainnya. Berdasarkan nilai Adjusted R Square sebesar 33,2 persen proses keputusan pembelian Zenbu PVJ dapat dijelaskan menggunakan variabel kualitas pelayanan, kualitas produk, store atmosphere dan $e-W O M$.

\section{Uji F}

Uji F digunakan untuk melihat pengaruh variabel bebas terhadap variabel terikat secara bersamasama.

Tabel 13 Tabel Hasil Uji F (Simultan)

\begin{tabular}{ccccccc}
\hline \multicolumn{1}{c}{ Model } & $\begin{array}{c}\text { Sum of } \\
\text { Square }\end{array}$ & df & $\begin{array}{c}\text { Mean } \\
\text { Square }\end{array}$ & F & Sig. \\
\hline 1 & Regresion & 559.738 & 4 & 139.934 & 13.326 & 0.000 \\
& Residual & 997.572 & 95 & 10.501 & & \\
Total & 1.557 .310 & 99 & & & \\
\hline
\end{tabular}

Sumber: Hasil pengolahan SPSS versi 23

Hipotesis yang telah dibuat sebelumnya adalah sebagai berikut.

$\mathrm{H}_{0}$ : Tidak terdapat pengaruh kualitas pelayanan, kualitas produk, store atmosphere, dan e-WOM Zenbu PVJ terhadap proses keputusan pembelian.

$\mathrm{H}_{1}$ : Terdapat pengaruh kualitas pelayanan, kualitas produk, store atmosphere, dan $e-W O M$ Zenbu PVJ terhadap proses keputusan pembelian.

Berdasarkan Tabel 13, maka diperoleh nilai $F$ hitung sebesar 13,326. Nilai $F$ tabel dapat diperoleh dari tabel $\mathrm{F}$ dengan mengetahui nilai $\mathrm{df}_{1}$ dan $\mathrm{df}_{2}$. Pada penelitian ini, nilai $\mathrm{df}_{1}$ sebesar empat dan nilai $\mathrm{df}_{2}$ sebesar 96 dan diperoleh nilai $\mathrm{F}$ tabel sebesar 2,47. Berdasarkan nilai $\mathrm{F}$ hitung dan $\mathrm{F}$ tabel yang sudah didapatkan, maka dapat disimpulkan bahwa nilai $\mathrm{F}$ hitung 13,326 lebih besar daripada nilai $\mathrm{F}$ tabel 2,47 dan dilihat dari nilai Sig., maka dapat disimpulkan bahwa nilai Sig. F lebih kecil daripada alpha 0,05 atau 0,000 lebih kecil daripada 0,05. Maka dapat disimpulkan bahwa terdapat pengaruh kualitas pelayanan, kualitas produk, store atmosphere, dan $e$-WOM terhadap proses keputusan pembelian Zenbu PVJ.

Hasil ini didapatkan karena sesuai dengan hasil penelitian Campbell \& Smith (1970) yang dikutip oleh Longart (2008) yang mengatakan bahwa makanan, store atmoshpere dan pelayanan yang meningkatkan daya tarik dari suatu restoran dan penelitian Lewis \& Chambers (2000) yang mengatakan bahwa $e$ WOM membantu konsumen untuk membuat 
keputusan bersantap di restoran saat keputusan tersebut beresiko cukup tinggi. Tentunya konsumen mempertimbangkan variabel makanan, store atmosphere, dan pelayanan dari suatu restoran sebelum bersantap ke restoran tersebut dan biasanya informasi mengenai ketiga variabel tersebut yang paling banyak diulas oleh konsumen yang telah berkunjung sebelumnya melalui media sosial atau website mereka sehingga keempat variabel tersebut secara simultan berpengaruh terhadap proses keputusan pembelian restoran dalam penelitian ini adalah Zenbu PVJ.

\section{IMPLIKASI MANAJERIAL}

Berdasarkan jawaban responden, diketahui beberapa indikator yang ada dalam variabel penelitian masih belum optimal sehingga dapat menjadi pertimbangan bagi pihak manajemen Zenbu PVJ untuk diperbaiki guna memperbesar produktifitas dan income Zenbu PVJ.

\section{Kualitas Pelayanan}

Dari hasil pengolahan data menyatakan kualitas pelayanan berpengaruh terhadap proses keputusan pembelian dan semakin tinggi kualitas pelayanan maka akan meningkatkan proses keputusan pembelian konsumen Zenbu PVJ. Maka ada satu indikator yang perlu diperhatikan oleh manajemen Zenbu PVJ. Karyawan Zenbu PVJ dinilai kurang cepat dalam menyajikan pesanan menurut responden. Hal ini mungkin dapat disebabkan karena setiap pesanan dibuat fresh dan dimasak saat pesanan masuk ke bagian dapur sehingga proses persiapan dan masak perlu dilakukan dengan waktu tertentu, tetapi lamanya proses tersebut masih kurang cepat walaupun masih dalam tahap yang wajar. Pihak manajemen dapat memperhatikan proses dari mulai pengambilan order hingga pesanan diantar ke konsumen dan menilai bagian mana yang menghambat proses tersebut sehingga dapat dilakukan perbaikan demi mempercepat pelayanan dan penyajian makanan/minuman kepada konsumen.

\section{Store Atmosphere}

Dari hasil pengolahan data menyatakan store atmosphere tidak berpengaruh terhadap proses keputusan pembelian tetapi dari persamaan regresi linearnya menunjukkan semakin tinggi Store Atmosphere maka akan meningkatkan proses keputusan pembelian konsumen Zenbu PVJ. Maka ada satu indikator yang perlu diperhatikan oleh manajemen Zenbu PVJ. a. Meja kasir Zenbu PVJ terletak cukup jauh di dalam ruangan restoran sehingga bila konsumen ingin melakukan transaksi pembayaran, konsumen harus berjalan ke dalam ruangan dulu lalu berjalan ke arah sebaliknya untuk keluar ruangan restoran yang menjadikan penilaian responden tidak tinggi.

b. Aroma ruangan dalam restoran Zenbu PVJ cukup wangi menurut responden. Tetapi karena penilaian responden belum tinggi sehingga seharusnya wewangian di dalam restoran bisa ditambah agar dapat menambah kenyamanan konsumen.

c. Musik yang diputar dalam restoran Zenbu PVJ cukup baik. Hal ini dapat dikarenakan musik yang diputar dalam restoran Zenbu PVJ kebanyakan adalah musik Jepang yang kurang familiar bagi kebanyakan responden.

d. Pencahayaan dalam restoran Zenbu PVJ cukup baik menurut responden. Hal ini dapat dikarenakan pencahayaan di dalam ruangan kurang terang yang mungkin bertujuan untuk memberikan efek relaksasi bagi konsumen.

e. Lahan parkir kendaraan di area Zenbu PVJ cukup luas sehingga responden cukup mudah mendapatkan parkir. Hal ini dapat dikarenakan letak Zenbu PVJ yang berada di dalam mall PVJ sehingga lahan parkir yang tersedia sangat terbatas dan diisi oleh pengunjung mall PVJ lainnya. Mungkin dapat disiasati dengan memberikan promo gratis 1 jam parkir bagi pengunjung yang bersantap pada nominal tertentu sehingga dapat menarik konsumen.

\section{3. $E-W O M$}

Hasil pengolahan data menyatakan e-WOM berpengaruh terhadap proses keputusan pembelian. Persamaan regresi linearnya menunjukkan semakin tinggi $e$-WOM maka akan meningkatkan proses keputusan pembelian konsumen Zenbu PVJ. Maka ada satu indikator yang perlu diperhatikan oleh manajemen Zenbu PVJ. Kurang aktifnya kegiatan $e$-WOM yang dilakukan Zenbu PVJ sehingga informasi yang beredar kurang banyak. Kurang banyak juga promo-promo yang diberikan bagi konsumen yang dapat memicu konsumen untuk membagikan pengalaman mereka bersantap di Zenbu PVJ melalui media sosial. Pihak manajemen dapat mengoptimalkan media sosial sebagai sarana pemasaran dan promosi yang baik bila dapat digunakan dengan baik dan tepat karena $e$-WOM melalui media sosial tidak memerlukan banyak biaya dan sangat praktis 
digunakan serta menjangkau sangat banyak calon konsumen lain.

\section{SIMPULAN}

Secara simultan, hasil analisis mendapatkan Sig. p-value 0,000 lebih kecil daripada 0,05 yang berarti terdapat pengaruh kualitas pelayanan, kualitas produk, store atmosphere dan e-WOM terhadap proses keputusan pembelian Zenbu PVJ. Hasil ini didapatkan karena konsumen mempertimbangkan variabel makanan, store atmoshpere dan pelayanan dari suatu restoran sebelum bersantap ke restoran tersebut dan biasanya informasi mengenai ketiga variabel tersebut yang paling banyak diulas oleh konsumen yang telah berkunjung sebelumnya melalui media sosial atau website mereka sehingga keempat variabel tersebut secara simultan berpengaruh terhadap proses keputusan pembelian restoran dalam penelitian ini adalah Zenbu PVJ.

Secara parsial, variabel kualitas pelayanan mendapatkan hasil Sig. p-value sebesar 0,042 lebih kecil daripada 0,05 yang berarti kualitas pelayanan berpengaruh terhadap proses keputusan pembelian Zenbu PVJ.Hasil ini sesuai dengan pernyataan dari Griffin (2017) yang mengatakan bahwa konsumen lebih terpengaruh terhadap kualitas pelayanan dibandingkan kualitas produk atau makanannya terutama untuk restoran-restoran yang mematok harga lebih mahal atau premium dibandingkan restoran lain yang menawarkan produk sejenis. Zenbu menawarkan produk dengan harga yang relatif lebih mahal dibandingkan restoranrestoran Jepang lainnya sehingga konsumen mengharapkan mendapatkan pengalaman dan pelayanan yang lebih baik. Maka hal tersebut yang dapat menyebabkan kualitas pelayanan berpengaruh terhadap proses keputusan pembelian.

Variabel $e$-WOM mendapatkan hasil Sig. $p$-value sebesar 0,000 lebih kecil daripada 0,05 yang berarti $e$-WOMberpengaruh terhadap proses keputusan pembelian Zenbu PVJ. Variabel $e$ $W O M$ juga menjadi variabel yang paling besar pengaruhnya dibandingkan dengan variabel lainnya dengan nilai Beta sebesar 0,301 sehingga variabel $e$-WOM memberikan dampak yang lebih besar terhadap keputusan pembelian. Hal ini dapat disebabkan karena $e-W O M$ menjadi salah satu pusat informasi yang paling mudah diakses melalui media sosial dan juga memberikan ulasan-ulasan yang jujur dan netral dari berbagai pengguna media sosial yang telah merasakan pengalaman bersantap di Zenbu PVJ. Maka variabel $e-W O M$ menjadi variabel yang berpengaruh terhadap proses keputusan pembelian.

Variabel kualitas produk mendapatkan hasil Sig. p-value sebesar 0,478 lebih besar daripada 0,05 yang berarti kualitas produk tidak berpengaruh terhadap proses keputusan pembelian Zenbu PVJ. Konsumen pada umumnya berpresepsi kualitas produk makanan yang ditawarkan di Zenbu PVJ yang terletak di suatu pusat perbelanjaan besar di Kota Bandung dan sudah berdiri lama sejak tahun 2006 akan sangat baik sehingga konsumen lain tidak terpengaruh dengan kualitas produk yang ditawarkan Zenbu PVJ dan lebih mempertimbangkan faktor lain dalam proses keputusan pembelian mereka.

Variabel store atmosphere mendapatkan hasil Sig.p-value sebesar 0,689 lebih besar daripada $0,05 y a n g$ berarti store atmosphere tidak berpengaruh terhadap proses keputusan pembelian Zenbu PVJ. Hal ini dapat disebabkan karena Zenbu PVJ berada di dalam mal PVJ di mana kebanyakan restorannya didesain dengan bentuk gedung dan ukuran yang hampir sama sehingga manajemen restoran tidak bisa terlalu banyak mengganti dekorasi atau merubah bentuk dasar dari restorannya. Selain itu peraturan PVJ mungkin membatasi kebebasan Zenbu untuk melakukan banyak perubahan dalam dekorasi ruangan restorannya yang menyebabkan store atmosphere tidak menjadi faktor yang dipertimbangkan oleh konsumen sebagai dasar dalam proses keputusan pembeliannya.

\section{SARAN}

Zenbu PVJ sudah cukup dikenal baik oleh masyarakat sebagai restoran Jepang Fushion yang menyajikan makanan dan minuman dengan kualitas yang baik maka agar tetap dapat menjaga image tersebut, pihak manajemen Zenbu PVJ perlu menjaga kualitas produknya. Zenbu PVJ perlu menjaga dan lebih meningkatkan kualitas pelayanan yang diberikan staff nya dengan memberikan training dan juga penyesuaian terhadap standar kualitas pelayanannya agar konsumen mendapatkan pelayanan yang lebih baik lagi. Hasil regresi linear berganda menunjukkan variabel kualitas pelayanan memberikan pengaruh terbesar kedua setelah $e$-WOM sehingga Zenbu PVJ perlu melakukan kontrol dan penyesuaian terhadap kualitas pelayanannya agar mendapatkan hasil yang signifikan.

Zenbu PVJ juga dapat menyusun strategi terkait aktivitas $e$-WOM yang mendorong baik 
dari internal maupun strategi yang mendorong pihak eksternal untuk melakukan aktivitas $e$ WOM seperti memberikan promo bagi konsumen yang mengunggah pengalaman bersantap mereka di Zenbu PVJ ke media sosial atau memberikan ulasan terhadap restoran Zenbu PVJ di website kuliner seperti ZOMATO dan sejenisnya. Hasil regresi linear berganda juga menunjukkan variabel $e$-WOM memberikan pengaruh yang paling besar dibandingkan variabel lainnya sehingga Zenbu PVJ perlu memberikan fokus yang lebih terhadap penyusunan strategi $e-W O M$ karena dapat memberikan dampak yang lebih besar.

Berdasarkan penilaian responden, Store Atmosphere dari Zenbu PVJ juga perlu mendapatkan beberapa perubahan seperti letak meja kasir yang kurang mudah dijangkau, aroma ruangan restoran yang kurang wangi dan lagulagu yang diputar masih kurang cocok di telinga konsumen sehingga mungkin dapat diselingi lagu yang lebih umum atau musik instrumen yang lebih nyaman didengar oleh konsumen.

\section{DAFTAR PUSTAKA}

Berman, B. \& Evans, J. (2001). Retail Management: A Strategic Approach. Edisi ke-10. New Jersey: Pearson Prentice Hall.

BPS Kota Bandung. (2017). Produk Domestik Bruto Regional Bandung Menurut Lapangan Usaha 2012 - 2016. Bandung: Badan Pusat Statistik Bandung.

Dian, N. \& Artanti. (2013). Pengaruh Kelompok Acuan dan Atmosfir Restoran Terhadap Keputusan Pembelian Konsumen Starbucks Coffee. Jurnal EMBA, Vol.3 No.1, 1162-1172.

Firdaus, T. \& Abdullah. (2017). E-WOM: Pengaruhnya Terhadap Keputusan Pembelian Tamu Restoran di Bandung Utara. Tourism and Hospitality Essentials Journal, Vol. 7, No. 1, 2126.

Goyette, I., Richard, L., Bergeron, J., \& Marticotte, F. (2010). E-WOM Scale:Word-of-Mouth Measurement Scale for e-Services Context. Journal of Administrative Sciences, 27, 5-23.

Griffith, K. (2017). In Restaurants, Ambiance and Service are More Important Than Food Quality. Diunduh dari University of Denver: http://news.du.edu/inrestaurants-ambiance-and-service-aremore-important-than-food-quality/
Jeong, E.H. \& Jang, S.C. (2011). Restaurant Experiences Triggering Positive Electronic Word-of-Mouth (e-WOM) motivations. International Journal of Hospitality Management, Vol 30(2), 356-366.

Kietzmann, J. \& Canhoto, A. (2013). Bittersweet! Understanding and Managing Electronic Word of Mouth. Journal of Public Affairs, 13(2), 146159.

Kotler, P. \& Keller, K. (2013). Manajemen Pemasaran. Terjemahan. Jilid 2. Jakarta: Penerbit Erlangga.

Lewis, C. \& Chambers, R. (2000). Marketing Leadership in Hospitality: Foundations and Practices. New York: John Wiley \& Sons.

Longart, P. (2010). What Drives word-of-mouth in Restaurants? International Journal of Contemporary Hospitality Management, 22 (1), 121-128.

Margaretha, F. (2012). Analisa Pengaruh Food Quality dan Brand Image Terhadap Keputusan Pembelian Roti Kecil Toko Roti Ganep's di Kota Solo. Jurnal Manajemen Pemasaran,1(1), 1-6.

Peter, J.P. \& Olson, J.C. (2013). Perilaku Konsumen dan Strategi Pemasaran. Terjemahan. Edisi Kesembilan.Jakarta: Penerbit Salemba Empat.

Petricia, D. \& Syahputra. (2015). Pengaruh Kualitas Produk, Harga, Promosi dan Kualitas Pelayanan terhadap Proses Keputusan Pembelian (Studi pada Konsumen Kopi Progo Bandung). Eproceeding of Management, 2(2), 2117 2124.

Rangkuti, F. (2006). Measuring Customer Satisfaction. Jakarta: PT Gramedia.

Rao, P. (2006). Measuring Consumer Perception Through Factor Analysis. The Asian Manager (February-March).

Ryu, K. \& Han, H. (2010). Influence of the quality of food, service, and physical environment on customer satisfaction in quick-casual restaurants: moderating role of perceived price. Journal of Hospitality and Tourism Research, 34(3), 310-329.

Sugiyono. (2009). Metode Penelitian Bisnis (Pendekatan Kuantitatif, Kualitatif, dan $R \& D)$. Alfabeta: Bandung.

Suliyanto. (2009). Metode Riset Bisnis. Edisi Kedua. Yogyakarta: Andi. 
Jurnal Manajemen Maranatha ש Vol. 18 Nomor 2, Mei (2019)

Utami, C.W. (2007). Manajemen Ritel: Strategi dan Implementasi Modern. Edisi Pertama. Jakarta: Salemba Empat.

Zeithaml, V., Parasuraman, A., \& Berry, L. (1985). Problems and Strategies in Services Marketing. Journal of Marketing, 49(2), 33-46. 